\title{
SEASONAL CHANGES IN THE PHYTO- PLANKTON AS INDICATED BY CHLOROPHYLL ESTIMATIONS
}

\author{
By W. R. G. Atkins, Sc.D., F.R.S. and Mary Parke, D.Sc. \\ From the Plymouth Laboratory
}

\section{INTRODUCTION}

When studying the suspended matter in sea water Armstrong \& Atkins (I950) filtered carboys of sea water taken from the surface at the International Hydrographic Station, England No. I, about Io miles south-west of the Eddystone. The samples averaged 22 1., filtered through a Whatman No. 50 paper, II cm. diameter, on a Buchner funnel with the water pump. The first Io 1. was always re-filtered. The results for the suspended matter were shown to be only about $4 \%$ less than when filtration was through ' Gradocol' collodion membranes of average pore diameter I.09 micron. The removal of the phytoplankton should thus be more complete than when the finest bolting silk is used, for according to Harvey (1945) the mesh apertures of the latter average $42 \times 50 \mu$ when wet and swollen. Since there are many flagellates and nonmotile forms less than $5 \mu$ in length it is obvious that the net may let through much that is retained by the cellulose or collodion filters.

The suspended matter thus obtained gave us the opportunity of following the changes in the phytoplankton in the surface water, by extracting the pigments with acetone-a method introduced by Kreps \& Verjbinskaya (I930), and by Harvey (I934 $a$ ) with more accurate measurement of the volume filtered by the nets. Riley (I938-4I) filtered surface samples through paper, as did Graham (I943). Krey at Kiel (I939) used 'cella'-presumably collodionfilters for water from 0-30 m. Cole \& Jones (I949) also have made plankton counts using collodion filters.

Before proceeding it is appropriate to consider the known plastid pigments of the phytoplankton and their abundance in typical species.

\section{The Plastid Pigments of the Phytoplankton}

In recent years these have received much attention. According to Rabinowitch's summary (I945), the chlorophylls constitute about two-thirds of the total plastid pigments, the remaining third consisting of carotenoids, of which one-fifth contains orange red carotenes, polyene hydrocarbons, and fourfifths consists of their oxygen derivatives, namely yellowish xanthophylls. The amounts vary with species and environment, but the relative proportions are fairly constant in growing cultures. Chloroplasts often appear yellowish 
or brown, rather than green, apparently due to the physical state of the plastid rather than to the preponderance of the yellow pigments.

According to Manning \& Strain (I943), diatoms contain chlorophyll $a$ and a little chlorophyll $c$, with carotenes and xanthophylls, mainly fucoxanthin, also diadinoxanthin and some diatoxanthin. The diatoms and brown algae have similar chlorophylls and xanthophylls. Pace (I94I), however, did not find fucoxanthin in Nitzschia closterium, but it has been proved by Whitford (I947) to exist in the Chrysophycean Phaeosphaera perforata. Calculated on the dry weight of Nitzschia closterium, Pace found $2 \cdot 17 \%$ chlorophyll $a$ and $0.155 \%$ chlorophyll $b$, also $\beta$-carotene, cryptoxanthin, lutein, isolutein and two xanthophylls. The chlorophyll-carotenoid ratio was $3 \cdot 77$.

The presence of the xanthophylls and carotenes, and sometimes of other pigments, makes direct colorimetric comparisons useless for the estimation of the mixed chlorophylls. Of these, Strain (1949) summarizes the absorptionband measurements, and for chlorophyll $a, \mathrm{C}_{55} \mathrm{H}_{72} \mathrm{O}_{5} \mathrm{~N}_{4} \mathrm{Mg}$, reports principal bands at 440 and $660 \mathrm{~m} \mu$; for chlorophyll $b, \mathrm{C}_{55} \mathrm{H}_{70} \mathrm{O}_{6} \mathrm{~N}_{4} \mathrm{Mg}$-which may constitute $20-40 \%$ of the chlorophyll of the Chlorophyta-the bands are at 480 and 650. In red algae and diatoms, however, Manning \& Strain (I943) found that $b$ was less than $0.3 \%$ of $a$. The position of the bands varies somewhat according to the solvent used.

The formula and molecular structure of $c$ is unknown, but it is found in small amounts along with chlorophyll $a$ in diatoms, dinoflagellates and brown algae; the absorption maxima, in ether, are given as $446,579.5$ and $627 \mathrm{~m} \mu$ (Strain, Manning \& Hardin, I944).

Chlorophyll $d$ is found in very small amounts, with $a$, in red algae, though up to $25 \%$ is $d$ in Rhodochorton rothii. It contains magnesium, but its formula is unknown. In ether its principal bands are at 445 and $686 \mathrm{~m} \mu$, and at about 457 and $698 \mathrm{~m} \mu$ in methanol (Manning \& Strain, I943).

\section{The Colorimetric Estimation of Chlorophyll and the Preparation of Extracts of Plastid Pigments from PHYTOPLANKTON}

On viewing acetone solutions of a bought dry solid chlorophyll and of various extracts from algal cultures and sea water with a hand spectroscope, the absorption in the red gave a well-marked band. By inserting the Schott RG I filter a spectrum of longer wave-length than $600 \mathrm{~m} \mu$ is obtained, between which and the end of the visible red the band may reduce the light very markedly, and so permit of colorimetric comparisons without interference from the yellow pigments. A Kober colorimeter (by Klett) was used for this work.

There is, however, an uncertainty in the composition of chlorophyll powder, such as that from the British Drug Houses. Nettle leaves may be used as a 
source. Though there are a number of chlorophylls and these have labile isomers the net effect of such changes as occur appears to be of no great importance as regards the absorption bands in the red; such small shifts in the bands would not seriously affect the colorimetric comparisons. Care should be taken to avoid errors due to evaporation of the acetone during the comparisons.

The aqueous acetone extracts from pure cultures of species selected from the phytoplankton (Parke, I949) were thus compared among themselves and with chlorophyll standards. The cell numbers were counted in the haemocytometer field. Table I shows the numbers of algal cells from active cultures of measured average size which yield I mg. of chlorophyll.

The solvent used was of 'analytical reagent' quality and was added to the wet filter-paper on which the algal cells had been collected and washed with distilled water. If necessary, to keep in solution the salts of sea water liberated from the cells, a little distilled water was added till the cloudiness in the acetone vanished.

The chlorophyll-bearing cells, from cultures or from sea water, vary in size down even to one micron in diameter, as we have found recently. They are accordingly too small to be retained quantitatively on filter-paper, such as Whatman No. 42, intended for the finest precipitates. The filtration of large volumes on the $4 \mathrm{~cm}$. diameter collodion membranes is very tedious and the membranes have to be changed frequently as they become choked. Centrifuging, even with tubes containing $250 \mathrm{ml}$. is unsatisfactory, and slow, though according to $\mathrm{H}$. W. Harvey (private communication) dead cells are deposited better than are living. The simplest method is to add $5 \mathrm{ml}$. of a $\mathrm{I} \%$ solution of potassium aluminium sulphate crystals to about a litre of culture or sea water. The samples are usually at about $\mathrm{pH} 8$, or over. The acid alum solution brings this nearer to neutrality; the reaction should be tested with bromthymol blue. If it is necessary to add more alum, for a very thick culture, the reaction may go slightly below neutrality, $\mathrm{pH}$ 7. If it is much below-in a fresh waterit can be restored by adding a little sodium bicarbonate. This is not done to precipitate the aluminium hydroxide which comes down from $\mathrm{pH}_{3.5}-5$, but to avoid any possible effect of acid on the pigments. According to Atkins (I922) the reaction of algal cells is close to neutrality, whereas land plants are often markedly acid. Trouble arises more frequently in dense cultures through the reaction of the water being too alkaline, $\mathrm{pH} 9$ or over. The aluminium does not then form a good floc, but either remains in solution or in a very fine suspension. The alkalinity may be reduced by passing in carbon dioxide, or by the cautious addition of very dilute acetic acid, till the $\mathrm{pH}$ is brought slightly below 7, and a yellowish green is given with bromthymol blue. This should be done before the addition of the alum solution, and it is advisable to allow the floc, with algae, to settle in weak light before filtration. It is often possible to pour off liquid over the floc, thus reducing time of filtration. Filtration 
may then be effected on an I I cm. Buchner funnel, with the filter pump. The rate should be low at first till the aluminium hydroxide floc has sealed the pores, when the suction may be increased. Unless too much alum has been added filtration proceeds at a reasonable rate. Algae from cultures are thus obtained for pigment studies, or it is possible to get the phytoplankton from I or 21 . of sea water to follow the rate of production in the sea; smaller volumes should suffice when plankton is abundant.

Algae carried down in the transparent floc are readily seen under the microscope. Dicrateria inornata was perfectly visible and only by very careful adjustment of the light was it possible to discern the floc. Cells of Chlamydomonas were observed to be actively motile after two filtrations with too little alum or with too alkaline a solution for effective flocculation.

The weight of the aluminium hydroxide floc which is effective is amazingly small; a I \% solution of potassium aluminium sulphate crystals contains only $0.82 \mathrm{mg}$. of the hydroxide in $5 \mathrm{ml}$. Yet in $100 \mathrm{ml}$. of sea water this gives a marked turbidity in a few minutes and a sediment about $4 \mathrm{~mm}$. in height in the measuring cylinder. Settling is naturally slower in a litre vessel, and as much as $15 \mathrm{ml}$., namely about $2.5 \mathrm{mg}$., may give with a culture a slowly filtering slime.

\section{THE CHLOROPHYLL CONTENT OF PURE ALGAL CULTURES}

A Gymnodinium culture contained I44 cells $/ \mathrm{mm}^{3}{ }^{3}$, (I44 million $/ 1$.) The cell numbers per milligram of chlorophyll were obtained as follows. A freshly diluted chlorophyll solution contained $16.0 \mathrm{mg}$. $/ 1$. Of this 50.0 matched 35.8 of a Gymnodinium extract, as read on the Kober scale, using filter RG I. The extract, therefore, contained $22.3 \mathrm{mg}$. $/ 1$.; and as its volume was $27.6 \mathrm{ml}$., which had been used in successive small portions to extract the algae filtered from $250 \mathrm{ml}$. of culture, the culture contained $2.46 \mathrm{mg}$. $/ 1$., in I44 million cells. So 58.5 million cells contain $\mathrm{I} \cdot 0 \mathrm{mg}$. The results for a number of species are given in Table I which include determinations on three species of diatom by Krey, Pace and Graham.

Differences in the volumes of the cells appear to account for the major differences in the milligram counts. One may not appreciate that, for example, the average volume of Coscinodiscus centralis is fourteen thousand times that of Dicrateria inornata.

To separate the pigments we tried aluminium oxide (Kahlbaum) specially prepared for such work. A blue green chlorophyll band was retained near the top; below this came one, or usually two, bands, orange red, and presumably carotenes. The liquid which came through was yellowish and appeared to be a xanthophyll, or several mixed perhaps. The above were obtained with the pigments in petroleum ether b.p. $40-60^{\circ} \mathrm{C}$. after evaporation of the acetone on a water-bath. Whitford (I947) has reviewed previous work; he separated 
the pigments on a starch column and with suitable solvent mixtures obtained bands for chlorophyll and two xanthophylls, the carotene coming through.

The separation of the chlorophylls can thus be readily effected and could be used as a check on the colorimetric comparison in the red.

Table I. Number of cells from Active Algal Cultures which yield I MG. OF Chlorophyll. Colour Refers to Extracts

\begin{tabular}{|c|c|c|c|}
\hline & \multicolumn{2}{|c|}{ Size } & \multirow{2}{*}{$\begin{array}{l}\text { Mg. } \\
\text { count }\end{array}$} \\
\hline & Mean $(\mu)$ & Range $(\mu)$ & \\
\hline & \multicolumn{3}{|c|}{ Chlorophyceae } \\
\hline \multicolumn{4}{|l|}{ Order VOLVOCALES } \\
\hline Chlamydomonas I, pure green. By F. Gross & $10 \times 5$ & $8 \times 4-I 2 \times 6$ & $202 \times 10^{6}$ \\
\hline $\begin{array}{l}\text { Chlamydomonas III, pure green. By Mrs } \\
\text { Föyn }\end{array}$ & $8 \times 6$ & $6 \times 4-12 \times 8$ & $109 \times 10^{6}$ \\
\hline \multicolumn{4}{|l|}{ Order CHLOROCOCCALES } \\
\hline Chlorella $\mathrm{I}$, yellowish green & $3.5 d$ & $2 \cdot 5-4 \cdot 5 d$ & $2400 \times 10^{6}$ \\
\hline \multirow{2}{*}{\multicolumn{4}{|c|}{ Chrysophyceae }} \\
\hline Order CHRYSOMONADALES & & & \\
\hline Dicrateria inornata Parke, yellowish green & $4 d$ & $3-5 \cdot 5 d$ & $563 \times 10^{6}$ \\
\hline \multicolumn{4}{|l|}{ Bacillariophyceae } \\
\hline \multicolumn{4}{|l|}{ Order CENTRALES } \\
\hline $\begin{array}{l}\text { Coscinodiscus centralis } \text { Ehr., yellowish } \\
\text { green. By R. Bainbridge }\end{array}$ & I IOd $\times 50 t$ & $\left\{\begin{array}{l}\operatorname{Ios} d \times 35 t \\
\operatorname{I} 40 d \times 60 t\end{array}\right.$ & $74 \times 10^{3}$ \\
\hline Chaetoceros gracilis Schütt (Krey, 1939) & $8 \times 6 b$ & - & $286 \times 10^{3}$ \\
\hline C. vanheurckii Gran (Graham, I943) & $24-28 w$ & -- & $170 \times 10^{3}$ \\
\hline Thalassiosira gravida Cleve, yellowish green & $22 d \times 12 t$ & $\begin{array}{l}20 d \times 10 t- \\
25 \times 14\end{array}$ & $123 \times 10^{6}$ \\
\hline \multicolumn{4}{|l|}{ Order PENNALES } \\
\hline $\begin{array}{l}\text { Nitzschia closterium (Ehr.) W.Sm. forma } \\
\text { minutissima. By Allen and Nelson; pure } \\
\text { green }\end{array}$ & $\begin{array}{l}30 \times 3- \\
8 \times 3 b\end{array}$ & $\begin{array}{l}25 \times 3- \\
35 \times 4\end{array}$ & $743 \times 10^{6}$ \\
\hline N. seriata Cleve (Pace, I94I) & $100 \times 6$ & - & $1 \cdot 25 \times 10^{6}$ \\
\hline \multicolumn{4}{|l|}{ Cryptophyceae } \\
\hline Order CRYPTOMONADALES & & & \\
\hline $\begin{array}{l}\text { Hemiselmis rufescens Parke, almost pure } \\
\text { green with insoluble red }\end{array}$ & $7 \times 4 \times 3$ & $\begin{array}{l}4 \times 3.5 \times 2- \\
8.5 \times 5 \times 3\end{array}$ & $3260 \times 10^{6}$ \\
\hline Dinophyceae & & & \\
\hline $\begin{array}{l}\text { Order DINOFLAGELlata } \\
\text { Gymnodinium sp. very close to G. simplex, } \\
\text { yellowish green }\end{array}$ & $15^{\star}$ & $10-22$ & $58 \times 10^{6}$ \\
\hline
\end{tabular}

Notes: $b$, body, without spines; $d$, diameter; $t$, thickness; $w$, width of cell; * sphaeroidal; $B y$, isolated by and maintained since at Plymouth.

\section{The Seasonal Changes in the Phytoplankton}

These have for many years been studied by the changes in concentration of phosphate and other nutrient salts. A number of isolated measurements have been made, as mentioned previously, but Harvey (1934 $b$ ) followed the changes at a station, $\mathrm{L}_{4}$, inside the Eddystone using a net filtering measured volumes of water and an arbitrary colorimetric scale compounded with potassium chromate and crystalline nickel sulphate.

There is, however, an uncertainty in the number of molecules of water of crystallization even in the 'analytical reagent' quality. The figure is between $6 \mathrm{H}_{2} \mathrm{O}$, taken by Harvey, and $7 \mathrm{H}_{2} \mathrm{O}$. The uncertainty is $6 \%$. A solution of 
known nickel content may, however, be prepared by dissolving nickel wire. The nickel chromate standards have been considered to be a tolerably good colour match for acetone extracts of plankton. We are indebted to Dr Harvey for kindly comparing an extract from plankton filtered from a carboy taken on 30 November I949 (Table II). This he assessed as corresponding to IO-I5 units in ro ml., but the extract was far more yellow than the standard, so a closer match was not possible. Viewing the tubes through the filter RGI, the sample was rather under 8 units, possibly as low as 6 units. Taking into account the volumes of extract and of water this corresponds to I.39-I.04 mg. of chlorophyll $/ \mathrm{m}^{3}$, using Harvey's value, based on Guthrie's work, of $0.3 \mu \mathrm{g}$. of chlorophyll/unit. The result found by comparison with a chlorophyll standard with the RG I filter was $1 \cdot 43 \mathrm{mg}$. $/ \mathrm{m}^{3}$. It seems possible that the yellower colour of the November extract may have been due to the presence of a larger number of flagellates than are ordinarily found in the net plankton to estimate which the colour units were devised.

Riley (1938) estimated chlorophyll from algae by comparison with a chlorophyll prepared by Dr C. G. Deuber of Yale. He separated the chlorophyll from the yellow pigments by saponifying it and removing the carotenoids in ethyl ether. He found I unit of the Harvey scale to correspond to $0.88 \pm$ ०.0I $\mu$ g. chlorophyll. There was good agreement between the dry organic matter and the chlorophyll content, but only in the upper layers of the water. Paper filtration (Whatman No. 44) was found to give up to seven times as much chlorophyll extract as did bolting silk, and use of collodion membrane produced about 6\% more than did paper in Long Island Sound (I94I $a$ ). Using the same method for removing the yellow pigments Riley tabulated Harvey units against chlorophyll for his Long Island work and the mean showed $0.26 \mu \mathrm{g}$. / unit. This is much below his earlier value, but agrees tolerably well with Harvey's estimated value $0.3 \mu \mathrm{g}$., which seems to accord reasonably well with the single comparison already quoted in this paper when the red filter was used. Riley also records that $\mathrm{I} 7 \cdot 44 \mathrm{mg}$. chlorophyll corresponded to $600 \mathrm{mg}$. dry organic matter, namely the chlorophyll was $2.9 \mathrm{I} \%$. This is close to Pace's value $2.32 \%$ for the sum of chlorophyll $a$ and $b$ in Nitzschia closterium, in which a lower value is to be expected as the analysis refers to a silica-bearing organism only.

The extracts made during 1948 and 1949 from suspended matter filtered on collodion from water from Station E I (which was selected to be beyond the range of fluctuation due to land drainage) were compared among themselves without the red filter and, using the filter, with chlorophyll solutions of suitable strength. The results are shown in Table II, together with the sea temperature, the suspended inorganic matter and ash after incineration(S.I.M.A.) and the percentage of silica contained in the latter, in order to see whether any relation existed between these and high chlorophyll values. No such relation is, however, observable. Thus 2020 and II $90 \mathrm{mg}$. $/ \mathrm{m}^{3}$ S.I.M.A. both have $44 \%$ 
of silica and correspond respectively to $\mathrm{I} \cdot 05$ and $\mathrm{I} \cdot 43 \mathrm{mg}$. of chlorophyll $/ \mathrm{m} .^{3}$. Furthermore, $490 \mathrm{mg} . / \mathrm{m}^{3}{ }^{3}$ S.I.M.A. had $43 \%$ of silica, but only $0.17 \mathrm{mg} . / \mathrm{m}^{3}$ of chlorophyll.

In 1948 the chlorophyll content was much as would be expected from the phosphate studies, with a well-marked maximum in April, and a lesser crest in October, separated by the year's minimum in mid-August. As always, a larger number of observations would have been better. For I949 the April figure observed was only half that of 1948 , but this was, after a drop, followed by a large outburst in June and a high maximum in July, leading, after fluctuations to a late November outburst rather greater than that observed in April. It must be remembered, however, that these observations are on

\section{Table II. Chlorophyll Content, with accompanying Surface Temperature, Suspended Inorganic Matter and Ash (s.I.M.A.), AND Silica Content of the LatTer}

Chlorophyll and S.I.M.A in mg./m. ${ }^{3}$ sea water (parts per thousand million). Silica in percentage of S.I.M.A.

\begin{tabular}{|c|c|c|c|c|c|c|c|c|c|}
\hline $\begin{array}{l}\text { DATE } \\
\text { I } 948\end{array}$ & Chlorophyll & ${ }^{\circ} \mathrm{C}$ & S.I.M.A. & $\mathrm{SiO}_{2} \%$ & $\begin{array}{r}\text { DATE } \\
\text { I } 949\end{array}$ & Chlorophyll & ${ }^{\circ} \mathrm{C}$ & S.I.M.A. & $\mathrm{SiO}_{2} \%$ \\
\hline Jan. & - & - & - & - & 5 Jan. & $0.6 I$ & $\mathrm{II} \cdot 2$ & 760 & $2 \mathrm{I}$ \\
\hline I I Feb. & - & IO. I & 一 & - & I Feb. & 0.86 & 10.2 & 1600 & 26 \\
\hline Io Mar. & 0.92 & 9.3 & - & - & I Mar. & 0.58 & $10 . \mathrm{I}$ & 740 & $2 \mathrm{I}$ \\
\hline I2 Apr. & $2 \cdot 84$ & $10 \cdot 2$ & - & - & I3 Apr. & $\mathrm{I} \cdot 37$ & 9.9 & 800 & 37 \\
\hline Io May & - & I 2.4 & - & - & 9 May & 0.57 & II. 5 & 800 & $3 \mathrm{I}$ \\
\hline 9 June & 0.73 & I $2 \cdot 6$ & I I 40 & 54 & 9 June & $3 \cdot 40$ & 13.9 & 1360 & 52 \\
\hline I5 July & 0.82 & I 4.7 & $2770^{\star}$ & 25 & 8 July & $4 \cdot 30$ & 16.5 & I880 & $4 \mathrm{I}$ \\
\hline Aug. & - & -1 & - & - & 8 Aug. & 0.36 & 15.3 & 450 & is \\
\hline I6 Aug. & $0 \cdot 17$ & 15.4 & 890 & 43 & I7 Aug. & 1.05 & 16.0 & 2020 & 44 \\
\hline 3 I Aug. & - & $16 \cdot 8$ & - & - & 29 Aug. & $0.5 \mathrm{I}$ & I9. 4 & 800 & 42 \\
\hline 4 Oct. & $I \cdot 22$ & $\mathrm{I} 4.7$ & 490 & 44 & 6 Oct. & - & 16.4 & 590 & 43 \\
\hline 30 Nov. & 0.30 & $13 \cdot 2$ & 950 & 17 & 8 Nov. & $I \cdot 43$ & $\mathrm{I} 4{ }^{\circ} \mathrm{O}$ & I I90 & 44 \\
\hline
\end{tabular}

surface water and there is now evidence from several sources that the surface is the seat of a large amount of suspended matter. None the less, the surface outbursts in June and July are remarkable.

When these figures $0.17-4.3 \mathrm{mg} . / \mathrm{m}^{3}$ chlorophyll are compared with values recorded by other workers, it is better to neglect the early net-filtered results, which are clearly low. The numerous measurements by Riley, filtering through the finest paper, would be low if the small flagellates were an important constituent. For surface samples from the North Atlantic he gives (I939) as mean I.2 and maximum $3.6 \mathrm{mg}$. $/ \mathrm{m}^{3}$, with 5.6 and 27.2 for George's Bank (I94I $b$ ) also 17.4 and 62.0 for Long Island Sound. Riley has recently (I949) given an extensive review of the subject. For La Jolla, Graham (I943) gives 0.77 and I. 86 maximum. His results appear to be low, as he reports no chlorophyll found in a sample in which $N$. seriata constituted $83 \%$ of the catch. His method of estimating the chlorophyll avoids errors due to the yellow pigments, for he used a visual spectrophotometer set at $668 \mathrm{~m} \mu$. with slit width 
$0.4 \mathrm{~mm}$. Krey (I939) used a 'cella' (collodion) filter and for 0-30 in. at Kiel got a mean of $2 \cdot 00 \mathrm{mg}$. $/ \mathrm{m}^{3}$ and a maximum of 5.00 .

It has been customary for biologists to count microscopic organisms on the ruled squares of the Thoma haemocytometer, the side of the ruled area being I $\mathrm{mm}$. and the depth one-tenth thereof. The volume is one-tenth of a cubic millimetre. It may serve to show how sparsely populated sea water is by recalling that the simultaneous utilization of all the phosphate present at the winter maximum in the English Channel suffices to produce $N$. closterium at a density of 2.7 per haemocytometer field (Atkins, I923). One milligram of phosphorus suffices for $2050 \times 10^{6}$ cells of $N$. closterium var. minutissima. When compared with the production of $743 \times 10^{6}$ cells for I mg. of chlorophyll (Table I) we see that the chlorophyll to phosphorus ratio is 2.76 in this species, weight for weight.

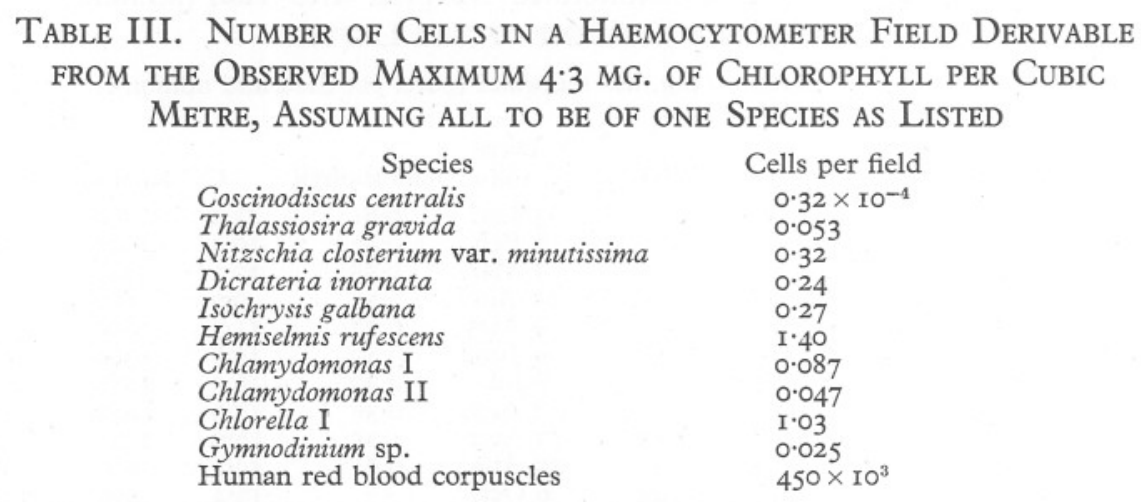

Table III shows the number of cells per field which would be produced if the maximum amount of chlorophyll recorded in Table II, namely $4.30 \mathrm{mg} . / \mathrm{m}^{3}{ }^{3}$, were all produced by the single species listed. It may be seen that, for Nitzschia, the observed maximum is only about one-eighth of the possible, were the winter maximum of phosphorus to give one crop without any intermediate grazing down; thus in a pure culture the chlorophyll produced by water of this composition would be about $4 \cdot 3 \times 8 \cdot 4$, namely $36 \mathrm{mg}$. $/ \mathrm{cm} .^{3}$.

The figures in the Table indicate the difficulty of making direct counts.

\section{SUMMARY}

The pigments of pure cultures of algae, of known number per volume, have been extracted with aqueous acetone after separation by filtration. The extracts were compared in a Kober colorimeter with standard solutions of a preparation of bought chlorophyll. The number required to give I mg. of chlorophyll was thus determined.

The algae studied included: Chlorophyceae, two species of Chlamydomonas and one Chlorella not yet described; Chrysophyceae, Dicrateria 
inornata Parke; Bacillariophyceae, Coscinodiscus centralis Ehr., Thalassiosira gravida Cleve and Nitzschia closterium (Ehr.) W.Sm. forma minutissima; Cryptophyceae, Hemiselmis rufescens Parke; Dinophyceae, Gymnodinium sp. The numbers per milligram of chlorophyll varied from $74 \times \mathrm{IO}^{3}$ for Coscinodiscus to over $3200 \times 10^{6}$ for Hemiselmis rufescens. Of the nine cultures, six were between 50 and $750 \times 10^{6}$. The volume of the cell is the deccisive factor in the milligram count.

Filtration of these and of sea-water samples was made through either collodion membranes of known average pore diameter, supplied by courtesy of the Director of the Department of Pathology, St Mary's Hospital, London, or through the finest grade of Whatman filter-paper. To retain the algal cells on paper about $5 \mathrm{ml}$. of a I \% solution of alum was added. The transparent floc serves to entangle the cells. They are thus ready for examination under the microscope, and motile organisms are slowed down or brought to rest. The floc will settle down in a cylinder. The water should be close to $\mathrm{pH} 7$ before addition of the alum.

Colorimetric estimation of chlorophyll can be made even with extracts which are yellowish green or yellow by using a red colour filter Schott RG I cutting off close to $0.6 \mu$, which is placed over the eyepiece of the colorimeter.

The seasonal changes in the chlorophyll content of water in the English Channel, about 20 miles off Plymouth, were followed from March I948 to November 1949 inclusive, by filtering surface water. The spring maxima in April were respectively $2 \cdot 84$ and $\mathrm{I} \cdot 37 \mathrm{mg}$. $/ \mathrm{m}^{3}$, and the autumn maxima $\mathrm{I} \cdot 22$ and $\mathrm{I} \cdot 43$. The yearly minima were in August, 0.17 and 0.36 . But most unexpectedly June and July I949 gave 3.40 and 4.30 respectively. Such figures are comparable with those of Krey, for Kiel, $2 \mathrm{mg}$. mean and $5 \mathrm{mg}$. maximum, and of Riley, for North Atlantic, I.2 mean and 3.6 maximum.

\section{REFERENCES}

Armstrong, F. A. J. \& Atkins, W. R. G., I950. The suspended matter of sea water. Fourn. Mar. Biol. Assoc., Vol. xxIx, pp. 139-43.

Atkins, W. R. G., I922. The hydrogen ion concentration of the cells of some marine algae. Fourn. Mar. Biol. Assoc., Vol. xII, pp. 785-8.

1923. The phosphate content of fresh and salt waters in its relationship to the growth of the algal plankton. Fourn. Mar. Biol. Assoc., Vol. xiII, pp. II9-50.

Cole, H. A. \& JoNES, E. W. K., I949. Quantitative estimation of marine nanoplankton. Nature, Vol. I64, pp. 694-6.

Graham, H. W., I943. Chlorophyll content of marine plankton. Fourn. Mar. Res., Vol. 5, pp. I53-60.

Harvey, H. W., I934a. Measurement of phytoplankton population. Fourn. Mar. Biol. Assoc., Vol. xIx, pp. 76I-73.

- I934b. Annual variation of planktonic vegetation, 1933. Fourn. Mar. Biol. Assoc., Vol. xIx, pp. 775-92.

- 1945. Recent Advances in the Chemistry and Biology of Sea Water. Cambridge University Press. I64 pp. 
Kreps, E. \& Verjbinskaya, N., 1930. Seasonal changes in the Barents Sea. fourn. Cons. Intern. Explor. Mer, Vol. v, pp. 329-45.

KREY, J., I939. Die Bestimmung des Chlorophylls in Meerwasserschöpproben. fourn. Cons. Intern. Explor. Mer, Vol. xIv, pp. $20 \mathrm{I}-9$.

Manning, W. M. \& Strain, H. H., I943. Pigments of algae. Carnegie Inst. of Washington Year Bk, Vol. 42, pp. 79-83, and Fourn. Biol. Chem., Vol. I5 I, pp. I-I9.

PACE, N., I94I. Pigments of the marine diatom Nitzschia closterium. Fourn. Biol. Chem. Vol. I40, pp. 483-9.

Parke, M., I949. Studies on marine flagellates. Fourn. Mar. Biol. Assoc., Vol xxviII, pp. $255-86$.

Rabinowitch, E. I., I945. Phytosynthesis and Related Processes. Vol. I. New York.

RILEY, G. A., I938. The measurement of phytoplankton. Int. Rev. Ges. Hydrobiol. Hydrogr. Bd. 36, pp. 371-3.

- I939. Plankton studies. II. The western North Atlantic, May-June I939. fourn. Mar. Res., Vol. 2, pp. I45-62.

- I94I $a$. Plankton studies. III. Long Island Sound. Bull. Bingham Oceanogr. Coll., Vol. vil, No. 3, pp. I-93.

- I94I b. Plankton studies. IV. Georges Bank. Bull. Bingham Oceanogr. Coll., Vol. vir, No. 4, pp. I-73.

- 1949. Quantitative ecology of the plankton of the western North Atlantic. Bull. Bingham Oceanogr. Coll., Vol. xII, No. 3, pp. I-169.

Strain, H. H., I949. Photosynthesis in Plants. Edited J. Franck and W. E. Loomis. Section 6. Ames, Iowa.

Strain, H. H., Manning, W. M. \& Hardin, G., I944. Xanthophylls and carotenes of diatoms, brown algae, dinoflagellates and sea anemones. Biol. Bull. Woods Hole, Vol. 86, pp. I69-9I.

Whitford, L. A., I947. A study of some algal pigments. Fourn. Elisha Mitchell Sci. Soc., Vol. 63, pp. I55-62. 